\title{
Efficacy and Profitability of Insecticide Treatments for Tomato Spotted Wilt Management on Peanut in South Carolina
}

\author{
Daniel J. Anco, ${ }^{1, \dagger}$ James S. Thomas, ${ }^{1}$ and Walter S. Monfort ${ }^{2}$ \\ ${ }^{1}$ Department of Plant and Environmental Sciences, Edisto Research and Education Center, Clemson University, Blackville, \\ SC 29817 \\ ${ }^{2}$ Department of Crop and Soil Sciences, University of Georgia, Tifton, GA 31793
}

\begin{abstract}
Tomato spotted wilt (TSW) is a common and serious disease of peanut (Arachis hypogaea L.) caused by Tomato spotted wilt virus (TSWV; family Tospoviridae, genus Orthotospovirus). Management frequently uses an integrated approach, with cultivar resistance and application of in-furrow insecticide as two critical components. In-furrow insecticides help suppress thrips, which can injure and stunt young growing plants and transmit TSWV, with postemergent application of acephate capable of providing additional thrips control. To examine effects of systemic insecticides (imidacloprid, imidacloprid plus fluopyram, phorate, and acephate) on TSW management, yield, and economic return across cultivar susceptibilities (susceptible, moderately susceptible, and resistant) in South Carolina, a meta-analysis was used to synthesize results

relative to nontreated controls. In-furrow treatments followed by acephate further reduced TSW incidence and increased profitability. All examined treatments improved yield compared with untreated peanuts except for susceptible cultivars treated with imidacloprid. Imidacloprid plus fluopyram increased yield more than imidacloprid alone for the susceptible group, although there was little difference between these treatments in association with moderately susceptible cultivars. When comparing individual applications, phorate was overall the most profitable option across susceptibilities, although imidacloprid plus fluopyram exhibited analogous profitability for susceptible cultivars. Results from this study can be used to assist producer selection of management options for TSW in peanut.
\end{abstract} from 32 studies conducted between 2009 and 2018. Although efficacy and magnitude of individual treatments varied with susceptibility, imidacloprid increased, whereas phorate generally decreased TSW incidence
Keywords: Arachis hypogaea, in furrow, tomato spotted wilt virus, quantitative synthesis
Tomato spotted wilt (TSW) is a serious disease of peanut (Arachis hypogaea L.) caused by Tomato spotted wilt virus, which is vectored by thrips (Frankliniella fusca [Pergande] and Frankliniella occidentalis [Hinds]), has $>1,000$ hosts, and is endemic in the southeastern United States (Culbreath et al. 2003; Hurt et al. 2005; Pappu et al. 2009; Parrella et al. 2003; Sherwood et al. 2009; Todd et al. 1995). Infections may be asymptomatic or include chlorotic ring spots, mottling and streaking on leaves, stunted growth, deformed pegs and kernels, corky pods, discolored testa, root necrosis, and plant death (Costa 1941; Culbreath et al. 1992; Halliwell and Philley 1974; McKinney and Tillman 2017; Srinivasan et al. 2017). As part of an integrated pest management (IPM) approach, several tactics are recommended and utilized to lower the risk of thrips injury and subsequent TSW development. These include using less susceptible cultivars, planting during a time when thrips populations are lower (mid-May in South Carolina), use of conservation tillage, planting at recommended seeding rates to establish a crop stand $>13.3$ plants $\mathrm{m}^{-1}$, twin row patterns, and application of in-furrow and postemergence systemic insecticides (Anco et al. 2018; Brandenburg 2017; Culbreath et al. 2003; Kemerait et al. 2018; Mahoney et al. 2018). Factors that potentially may inhibit implementation vary with individual management tactics. Planting in twin rows, strip tillage, or no till requires specialized equipment. Cultivar choice is economically and practically affected by contract and seed availability, and

${ }^{\dagger}$ Corresponding author: D. J. Anco; danco@clemson.edu

Funding: We thank the South Carolina Peanut Board and the National Peanut Board for supporting this work. This material is based on work supported by National Institute of Food and Agriculture project SC-1700532.

The author(s) declare no conflict of interest.

Accepted for publication 30 October 2019.

() 2020 The American Phytopathological Society adverse weather, total farm acreage, and multiple concurrent farm operations can influence the time that peanuts are actually planted in the field. Increasing plant populations can increase production costs and is associated with seed size of the cultivar planted.

Even with the presence of multiple IPM strategies for reducing thrips and TSW risk, the utility of early-season insecticide protection remains an important, economical, and time-efficient practice because current contract prices and costs of production do not provide ample room for peanut yield loss, whereas at-planting application logistically only additionally requires acquisition, measuring, calibration, and addition to the spray tank or hopper. The main chemistries currently used in South Carolina for in-furrow management of thrips in peanuts include imidacloprid (approximately \$20/ha), imidacloprid plus fluopyram (approximately $\$ 84 / \mathrm{ha}$ ), and phorate (approximately $\$ 38 / \mathrm{ha}$ ), with aldicarb being reregistered on peanuts. Although aldicarb has been demonstrated to effectively manage both thrips and nematodes (Childers et al. 1987; Minton and Morgan 1974; Smith 1972), currently limited product supply and its relatively higher cost (approximately $\$ 104 /$ ha for the labeled thrips rate) have limited the extent of its use for growers managing peanuts in the absence of nematodes in South Carolina. If in-furrow insecticides do not provide adequate thrips control, a postemergent foliar application of acephate (approximately \$19.77/ha) may prevent further thrips damage and potential yield loss (Herbert et al. 2007). Beyond these cultural and chemical tactics, the lack of additional management options for TSW during the remainder of the growing season underscores the importance for growers to maximize efficacy of IPM choices at the onset of the growing season.

In addition to control of the thrips vector alone, choice of in-furrow insecticide can additionally influence management of TSW, fungal diseases, and nematodes. Although both aldicarb and fluopyram have nematicidal activity (Childers et al. 1987; Faske and Hurd 2015; Jackson et al. 2014; Minton and Morgan 1974; Oka and Saroya 2019; Smith 1972), fluopyram is additionally a fungicide (Proffer et al. 2013; Veloukas and Karaoglanidis 2012). Imidacloprid has been documented to increase TSW incidence (Culbreath and Srinivasan 2011; Marasigan et al. 2016, 2018; Srinivasan et al. 
2017), whereas phorate decreases TSW incidence beyond thrips control alone (Culbreath et al. 2008; Jain et al. 2015). To reduce the risk of imidacloprid increasing TSW incidence, products containing this compound could be paired with a resistant cultivar (Anco et al. 2018; Brandenburg 2017; Kemerait et al. 2018; Mehl 2017), with insecticide response differing by cultivar as previously documented (Culbreath et al. 2008, 2016). In light of production conditions varying among situations, the ability of one product over another to manage a particular set of pests to contribute to yield production and overall farm profitability is highly relevant. However, the convenience of applying a particular product also contains value because liquid formulations have seen increased adoption over granular in-furrow insecticides across states, with some use estimates at $40 \%$ of peanut hectarage (Brandenburg et al. 2019; Morgan et al. 2014; Srinivasan et al. 2017). Coapplication of several agrochemicals (Jordan et al. 2018a) is a related practice to reduce the time otherwise required to apply products separately, and this approach similarly extends to in-furrow application of insecticide and Bradyrhizobium inoculant during planting (Jordan et al. 2018b). The objective of this study was to examine the performance of common insecticide treatments applied early in the growing season for TSW management, associated yield increase, and profitability for peanut cultivars of varying susceptibility in South Carolina.

\section{Materials and Methods}

Study data. Data from 38 studies conducted in South Carolina from 2009 to 2018 were examined for meeting selection criteria for inclusion in the analyses. To be selected for inclusion, studies needed to have been conducted with a minimum of two insecticide treatments per cultivar, report which cultivar was grown, contain data on TSW incidence (estimated from foliar symptoms as described in Cantonwine et al. 2006 and Culbreath et al. 1997) and yield per treatment, and contain information necessary to calculate the study sampling variance (Madden and Paul 2011; Ngugi et al. 2011; Paul et al. 2008). Where yield was reported, studies needed to be free of observed confounding factors, such as nontarget diseases or substantially delayed harvest. Furthermore, for cultivar-insecticide treatment combinations to be included in the analysis, they needed to be present in a minimum of four studies. Based on these criteria, 32 datasets were selected for further analysis. Of these studies, 29, 2 , and 1 were conducted at the Clemson University Edisto Research and Education Center in Blackville (2009 to 2018; Barnwell loamy sand), the Pee Dee Research and Education Center in Florence (2017 and 2018; Norfolk loamy sand), and a commercial field in Fairfax, South Carolina (2017; Noboco loamy sand), respectively. Planting date per study ranged from late April to late May. Planted cultivars were classified into three relative susceptibility groups (susceptible, moderate, and resistant) based on field performance (Anco et al. 2018). The susceptible group included cultivars FloRun 157 ( $n=5$ trials) and TUFRunner $511(n=21$ trials). The moderate group included cultivars CHAMPS ( $n=5$ trials), FloRun 331 ( $n=3$ trials), Georgia 06G ( $n=20$ trials), Georgia 09B ( $n=2$ trials), Georgia $16 \mathrm{HO}$ ( $n=3$ trials), and NCV-11 ( $n=4$ trials), and the resistant group included cultivars Bailey ( $n=5$ trials), Florida-07 ( $n=1$ trial), Georgia $12 \mathrm{Y}$ ( $n=1$ trial), Georgia 13M ( $n=1$ trial), Sullivan ( $n=8$ trials), TifNV-High O/L ( $n=5$ trials), and TUFRunner 297 ( $n=3$ trials). Imidacloprid (e.g., Admire Pro 4.6F; Bayer CropScience) and imidacloprid plus fluopyram (Velum Total 2.17F; Bayer CropScience) were applied in furrow at planting with a D2 orifice at 98 liters/ha and $221 \mathrm{kPa}$ at rates of 402 and 340 , respectively, plus $240 \mathrm{~g}$ a.i./ ha phorate (Thimet 20G; AMVAC Chemical Corporation) was applied in furrow at planting at 5,268 $\mathrm{g}$ a.i./ha with a SmartBox. Acephate (e.g., Orthene 97SP; AMVAC Chemical Corporation) was applied approximately 21 days after planting at $819 \mathrm{~g}$ a.i./ha with two DG8002 nozzles per row mounted on a boom set to deliver 169 liters/ha at $345 \mathrm{kPa}$ with a $\mathrm{CO}_{2}$-pressurized backpack sprayer. Total numbers of studies containing each insecticide treatment per susceptibility group are listed in Table 1. Experimental design for all studies was a randomized complete block with treatments replicated 2 to 13 times. Plot size was 3.9-m wide (four rows on 0.97-m centers) by $12.2 \mathrm{~m}$. Beyond insecticide treatments, peanuts were managed according to Extension-recommended practices for South Carolina (Anco et al. 2018) (i.e., to limit influence of nontarget diseases, etc.). Yield was obtained from two rows per plot $(1.95 \times$ $12.2 \mathrm{~m}$ ) using a Hobbs two-row combined fitted with a load cell basket, and it was standardized to $10 \%$ moisture.

Meta-analysis of insecticide effect on spotted wilt incidence and yield. Two-stage multitreatment unconditional network metaanalysis (Madden et al. 2016; Piepho et al. 2012; Sylvester et al. 2018; Willyerd et al. 2015) was used to estimate treatment responses for proportion TSW incidence and kilograms per hectare yield data (Hedges et al. 1999; Paul et al. 2007, 2008). Per each dataset, least squares means of treatment TSW incidence and log yield were first obtained through separate linear mixed models incorporating block as a random effect. Study estimates, weighted via the inverse of corresponding study sampling variance, were then analyzed together using the GLIMMIX procedure of SAS (SAS 9.4) with restricted maximum likelihood and Kenward-Roger degrees of freedom adjustment. In the case of the TSW incidence data, study sampling variance $\left(S_{i j k}{ }^{2}\right)$ was equivalent to the quotient of estimated intrastudy residual variance $\left(V_{i}\right)$ and number of treatment replicates per study $\left(n_{i}\right)$. To obtain study sampling variances for yield on the raw kilograms per hectare scale $\left(S_{i j k}^{2}\right.$ raw $)$, sampling variances were calculated as

$$
S_{i j k}^{2}{ }_{\text {raw }}=S_{i j k}^{2}{ }_{l o g} \times y_{i j k}^{2}{ }_{\text {raw }}=\left(V i_{-l o g} / n_{i}\right) \times y_{i j k}^{2} \text { raw }
$$

where $y_{i j k}{ }_{\text {raw }}^{2}=\exp \left(y_{i j k \_l o g}\right)^{2}$ and $y_{i j k \_l o g}$ estimates were as obtained from the linear mixed models analyzed within the first stage of the meta-analysis (subscripts are explained after equation 2). Response variables were modeled according to a Gaussian distribution. Cultivar susceptibility was included in the model as a moderator variable (van Houwelingen et al. 2002; Whitehead 2002). In the second stage of the meta-analysis, data were modeled using equation 2 :

$$
y_{i j k}=\delta_{j k}+u_{i j}+\varepsilon_{i j k}
$$

where $y_{i j k}$ is the mean (proportion TSW incidence or kilograms per hectare yield) response for the $i$ th study, $j$ th treatment, and $k$ th susceptibility group; $\delta_{j k}$ is the fixed effect of the $k$ th susceptibility group ( $k=$ susceptible, moderately susceptible, or resistant; selected to facilitate interpretation of current and plausibly, future cultivars for which a relative susceptibility group can be associated) and $j$ th treatment on the effect size; $u_{i j}$ is the random effect of the $i$ th study on the $j$ th treatment effect; and $\varepsilon_{i j k}$ is the residual (held at one). Terms not appearing in equation 2 were either intentionally excluded (e.g., model intercept) or removed ex post facto (e.g., random study effect

Table 1. Frequency of insecticide treatments among cultivars of varying susceptibility to tomato spotted wilt virus within 32 studies conducted in South Carolina from 2009 to 2018

\begin{tabular}{lcc}
\hline Susceptibility and treatment $^{\mathbf{a}}$ & Studies & Years \\
\hline Susceptible & 12 & \\
$\quad$ Imidacloprid & 4 & 4 \\
Imidacloprid followed by acephate & 5 & 3 \\
Imidacloprid plus fluopyram & 15 & 4 \\
Phorate & 11 & 4 \\
$\quad$ Untreated control & 13 & 4 \\
Moderate & 4 & 5 \\
Imidacloprid & 7 & 3 \\
Imidacloprid followed by acephate & 24 & 5 \\
Imidacloprid plus fluopyram & 20 & 9 \\
Phorate & & 9 \\
Untreated control & 5 & \\
Resistant & 13 & 6 \\
Imidacloprid & 8 & 6 \\
Phorate & & 5 \\
Untreated control &
\end{tabular}

${ }^{a}$ Imidacloprid, phorate, and imidacloprid plus fluopyram were applied in furrow at planting; acephate was broadcast approximately 21 days after planting. 
$\beta_{i}$ was estimated to be zero). Significance of model fixed effects was evaluated using type III tests of fixed effects as part of standard GLIMMIX output (Littell et al. 2006). Covariance structure of the random study treatment effect $u_{i j}$ was a first-order multiplicative structure (Madden et al. 2016) selected by way of lowest Akaike's Information Criterion (AIC) (Littell et al. 2006) among candidate covariance structures tested. For the TSW incidence model, this corresponded to a value of -456.6 compared with the similar yet insubstantially lower AIC $(-458.3)$ from the more complex second-order multiplicative structure. The first-order multiplicative structure similarly yielded the lowest AIC $(2,391.7)$ for the yield model, which was comparable with yet lower than the same measure when fitted to the expanded version of this structure that allowed for additional variance heterogeneity (second-order multiplicative): 2,394.2. Beyond the parsimonious reductions in log-likelihood functions obtained with these fitted models as assessed with AIC, utilization of the first-order multiplicative structure bestowed the additional benefit of integrating treatment-level between-study variances as a function of the sensitivity of the $j$ th treatment to the $i$ th study (Piepho et al. 2012), consequently facilitating the analyses to be directly performed on the data scales. Contrasts of the $\delta_{j k}$ elements (treatments within cultivar susceptibility groups) and associated $95 \%$ confidence limits were estimated using the lsmestimate statement in GLIMMIX.

A more complicated model incorporating an interaction with another moderator variable representing baseline TSW incidence in a study (1: equivalent to $<5 \%$ for nontreated moderately susceptible cultivars or 2 : equivalent to $\geq 5 \%$ for nontreated moderately susceptible cultivars) was initially considered, but it was ultimately disregarded in part in favor of using the simpler model. More intentionally, this choice involved the practical basis that, although likelihood of a given TSW risk as a function of implemented IPM practices can be conveyed (Anco et al. 2018; Brandenburg et al. 2019; Kemerait et al. 2018; Srinivasan et al. 2017), the actual amount of subsequent TSW incidence that will develop in a given field is often not precisely known at the time when decisions regarding cultivar and in-furrow insecticide decisions are made. Excluding the baseline TSW incidence factor additionally resulted in larger overall representation of treatment-susceptibility combinations present per total number of studies. Other moderator variables examined that did not improve the fitted models included planting date (1: planted prior to 1 May; 2: planted 1 to 10 May; and 3: planted 11 to 25 May; trials planted after 25 May were not present in the analyzed data) and year (continuous variable: 2009 to 2018).

Projected yield increase and return. The probability of an individual treatment having a greater yield than the untreated control per cultivar susceptibility was calculated based on variance-covariancederived between-trial standard deviation, $\widehat{\sigma}_{D_{j k}}$, and cumulative standardnormal function, $\Phi(\bullet)$, methodology (Paul et al. 2008; Sylvester et al. 2018; van Houwelingen et al. 2002; Willyerd et al. 2015). Formulaically, probabilities were calculated as

$$
p_{j k}=1-\Phi\left(\frac{C-D_{y_{j k}}}{\widehat{\sigma}_{D_{j k}}}\right)
$$

where $C$ is a given yield increase or constant, $D_{y j k}$ is yield above the nontreated control for the $j k$ th treatment-susceptibility group, and $\widehat{\sigma}_{D_{j k}}$ was calculated as per Paul et al. (2008) as

$$
\widehat{\sigma}_{D_{j k}}=\sqrt{\widehat{\sigma}_{T S G_{j k}}^{2}+\widehat{\sigma}_{U T C_{k}}^{2}-2 \widehat{\sigma}_{T S G_{j k}, U T C_{k}}}
$$

where $\widehat{\sigma}_{T S G_{j k}}{ }^{2}, \widehat{\sigma}_{U T C_{k}}{ }^{2}$, and $\widehat{\sigma}_{T S G_{j k}, U T C_{k}}$ are the estimated variance of treatment-susceptibility group $j k$, the estimated variance of the untreated control for the $k$ th susceptibility group, and the estimated covariance between treatment-susceptibility group $j k$ and the corresponding untreated control, respectively.

Returns from yield increases were estimated using a peanut contract price of $\$ 468.5$ per $1,000 \mathrm{~kg}(Q)$, an example (runner market type) contract price in South Carolina in 2018 left static across cultivar susceptibility groups here for convenience as well as to produce fairly conservative estimated returns. Imidacloprid, phorate, acephate, and imidacloprid plus fluopyram were set at $\$ 20.46$, $38.05,19.77$, and 84.07/ha, respectively, based on local prices in 2018. Treatment return $\left(R_{j k}\right)$ above the untreated control for treatmentsusceptibility $j k$ was calculated as

$$
R_{j k}=\left(D_{y j k} \times Q\right)-W_{j}
$$

where contract price $Q$ and $D_{y j k}$ were as described above and $W_{j}$ is the treatment cost (dollars) per hectare for the $j$ th treatment.

\section{Results}

Study data summary. Across the trials, incidence of TSW in nontreated cultivars classified as susceptible, moderate, and resistant ranged from 4.9 to $32.5 \%$, from 1.3 to $26.3 \%$, and from 0 to $4.5 \%$, respectively (Fig. 1A), with corresponding medians of 11.4, 5.8, and $2.2 \%$, respectively. Incidence following imidacloprid treatment as opposed to nontreated or phorate-treated peanuts was greater across the same cultivar groups, with ranges (medians) at 3.9 to $52.2 \%(15.2 \%), 4.4$ to $38.8 \%(9.1 \%)$, and 4.0 to $24 \%$ (5.6\%), respectively. In comparison with nontreated or imidacloprid-treated peanuts, phorate overall was associated with lower incidence: 23.6 to $31.4 \%(5.9 \%), 0$ to $16.8 \%(3.1 \%)$, and 0 to $15.7 \%(2.8 \%)$, respectively. Incidence of susceptible and moderate cultivars treated with imidacloprid plus fluopyram ranged (median) from 4.6 to $40.9 \%$ (17.8\%) and from 5.8 to $31.9 \%$ (12.0\%), respectively. Imidacloprid followed by acephate for susceptible and moderate cultivars ranged from 3.9 to $39.2 \%$ and from 7.2 to $25.6 \%$, respectively, with medians of 10.8 and $8.4 \%$, respectively.

Yield in untreated susceptible, moderate, and resistant cultivars ranged from 2,180 to $5,960 \mathrm{~kg} / \mathrm{ha}$, from 2,170 to $5,950 \mathrm{~kg} / \mathrm{ha}$, and from 4,120 to $6,570 \mathrm{~kg} / \mathrm{ha}$, respectively (Fig. 1B) across the trials, with corresponding medians of 5,110, 4,600, and $5,230 \mathrm{~kg} / \mathrm{ha}$. Imidacloprid treatment yield ranged (medians) from 2,440 to 6,290 $\mathrm{kg} / \mathrm{ha}(5,380 \mathrm{~kg} / \mathrm{ha})$, from 2,290 to $5,790 \mathrm{~kg} / \mathrm{ha}(4,750 \mathrm{~kg} / \mathrm{ha})$, and from 3,260 to $5,500 \mathrm{~kg} / \mathrm{ha}(5,360 \mathrm{~kg} / \mathrm{ha})$, respectively, across these groups. Yield of cultivars following phorate treatment was slightly higher at 2,450 to $6,280(5,500), 2,560$ to $6,610(5,140)$, and 3,670 to $7,040 \mathrm{~kg} / \mathrm{ha}(5,310 \mathrm{~kg} / \mathrm{ha})$, respectively, compared with that of those treated with imidacloprid. Imidacloprid followed by acephate for susceptible and moderate cultivars ranged from 5,330 to 6,550 $\mathrm{kg} / \mathrm{ha}$ and from 4,590 to $5,950 \mathrm{~kg} / \mathrm{ha}$, respectively, with medians of 5,630 and $5,400 \mathrm{~kg} / \mathrm{ha}$, respectively. Incidence of susceptible and moderate cultivars treated with imidacloprid plus fluopyram ranged (median) from 4,990 to $6,140 \mathrm{~kg} / \mathrm{ha}(5,560 \mathrm{~kg} / \mathrm{ha})$ and from 2,080 to $5,550 \mathrm{~kg} / \mathrm{ha}(4,340 \mathrm{~kg} / \mathrm{ha})$, respectively.

Meta-analysis results. Incidence of treatment TSW was affected by the moderator variable cultivar susceptibility $\left(\delta_{j k}, P<0.0001\right)$. Within each of the three susceptibility groups, treatment with imidacloprid was associated with greater $(P<0.035)$ TSW incidence than the untreated check, with this difference being similar among the three groups and overall ranging from 2.2 in the moderate group ( $95 \%$ confidence interval [95\% CI]: 0.2 to $4.2 \%$ ) to $3.2 \%$ in the resistant group (95\% CI: 0.4 to 5.9\%) (Fig. 2A). Treatment with imidacloprid plus fluopyram increased TSW incidence to a similar degree, ranging in whole from $2.8(P=0.0345)$ to $3.1 \%(P=0.0089)$ for susceptible and moderate cultivars, respectively, with corresponding confidence limits of 0.2 to 5.4 and 0.8 to $5.4 \%$, respectively. Phorate significantly reduced TSW incidence in the susceptible $(6.0 \%)$ and moderate $(4.4 \%)$ groups $(P<0.0001)$, but it was not associated with a reduction with resistant cultivars $(P=0.1560)$.

Imidacloprid followed by acephate reduced TSW incidence compared with imidacloprid alone $(P<0.049$ for susceptible and moderate cultivars), with the resulting difference between imidacloprid followed by acephate and the untreated check not different from $0(P>0.56)$, being $-0.6 \%$ (95\% CI: -3.7 to $2.5 \%)$ for susceptible cultivars and -0.9 (95\% CI: -3.8 to $2.1 \%$ ) for the moderate group. Although the difference between imidacloprid followed by acephate and phorate was smaller in magnitude compared with imidacloprid 
alone (3.6 and 5.4\% versus 6.7 and $8.4 \%$ for moderate and susceptible cultivars, respectively), these differences were still significant $(P<0.029)$. The addition of fluopyram to imidacloprid did not affect TSW incidence compared with imidacloprid alone $(P>0.4)$.

As with the incidence data, the susceptibility moderator variable affected treatment yield $\left(\delta_{j k}, P<0.0001\right)$. With the exception of susceptible cultivars treated with imidacloprid $(99 \mathrm{~kg} / \mathrm{ha}, P=0.3213$; 95\% CI: -100 to $300 \mathrm{~kg} / \mathrm{ha}$ ), all treatments per susceptibility group corresponded to significantly greater yield than their associated untreated check $(P<0.042)$ (Fig. 2B). When susceptibility-specific treatment contrasts were considered across susceptibility groups, imidacloprid, imidacloprid plus fluopyram, and phorate treatments increased yield over the untreated check by $260 \mathrm{~kg} / \mathrm{ha}$ (moderate; $P=0.0056 ; 95 \%$ CI: 80 to $440 \mathrm{~kg} / \mathrm{ha}$ ) to $280 \mathrm{~kg} / \mathrm{ha}$ (resistant; $P=$ $0.0388 ; 95 \%$ CI: 10 to $540 \mathrm{~kg} / \mathrm{ha}$ ), $240 \mathrm{~kg} / \mathrm{ha}$ (moderate; $P$ $=0.0410 ; 95 \%$ CI: 10 to $480 \mathrm{~kg} / \mathrm{ha}$ ) to $450 \mathrm{~kg} / \mathrm{ha}$ (susceptible; $P=$ 0.0011 ; $95 \%$ CI: 190 to $720 \mathrm{~kg} / \mathrm{ha}$ ), and $250 \mathrm{~kg} / \mathrm{ha}$ (susceptible; $P=0.0079 ; 95 \%$ CI: 70 to $430 \mathrm{~kg} / \mathrm{ha}$ ) to $500 \mathrm{~kg} / \mathrm{ha}$ (moderate; $P<$ 0.0001 ; $95 \%$ CI: 350 to $640 \mathrm{~kg} / \mathrm{ha}$ ), respectively. Imidacloprid in furrow followed by acephate 21 days after planting increased yield over the untreated check by $570 \mathrm{~kg} / \mathrm{ha}$ for moderate cultivars $(P=0.0051$; $95 \%$ CI: 170 to $960 \mathrm{~kg} / \mathrm{ha}$ ) and by $620 \mathrm{~kg} / \mathrm{ha}$ for susceptible cultivars $(P=0.0031 ; 95 \% \mathrm{CI}: 220$ to $1,030 \mathrm{~kg} / \mathrm{ha})$.
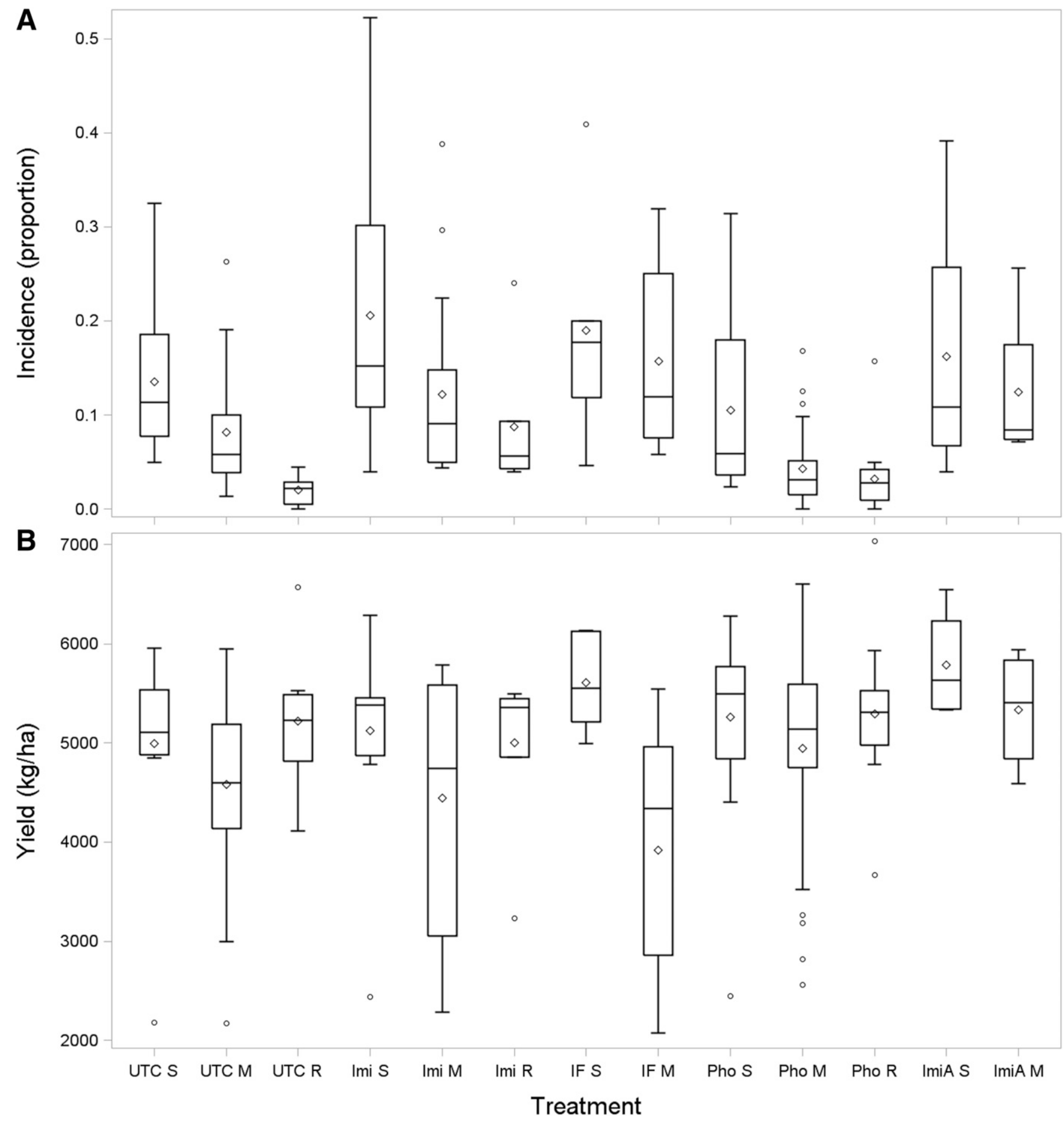

Fig. 1. Tomato spotted wilt $\mathbf{A}$, incidence and $\mathbf{B}$, yield associated with listed treatments per cultivar susceptibility group. Study means and medians are represented by the open diamonds and the solid horizontal lines, respectively; the first and third quartiles are represented by the lower and upper edges of the box, respectively, whereas the whiskers represent the range of values beyond the interquartile range but $\leq 1.5$ interquartile ranges. IF, imidacloprid plus fluopyram; Imi, imidacloprid; ImiA, imidacloprid followed by acephate 21 days after planting; M, moderately susceptible; Pho, phorate; R, resistant S, susceptible; UTC, untreated control. 
Compared with imidacloprid alone, imidacloprid followed by acephate increased yield of susceptible cultivars by $520 \mathrm{~kg} / \mathrm{ha}(P=$ 0.0122 ; $95 \%$ CI: 120 to $930 \mathrm{~kg} / \mathrm{ha}$ ), although this comparison was not significant for cultivars in the moderate group $(P=0.1264$; $95 \% \mathrm{CI}$ : -90 to $700 \mathrm{~kg} / \mathrm{ha}$ ). For the resistant group, both imidacloprid $(280 \mathrm{~kg} / \mathrm{ha}, P=0.0388 ; 95 \% \mathrm{CI}: 10$ to $540 \mathrm{~kg} / \mathrm{ha})$ and phorate $(320$ $\mathrm{kg} / \mathrm{ha}, P=0.0015 ; 95 \% \mathrm{CI}: 120$ to $510 \mathrm{~kg} / \mathrm{ha}$ ) increased yield over the untreated check, with the resulting difference between these pesticides not significant ( $P=0.7280$; $95 \%$ CI: -280 to $200 \mathrm{~kg} / \mathrm{ha})$. Phorate increased yield compared with imidacloprid $(230 \mathrm{~kg} / \mathrm{ha}, P=$ 0.0079 ; $95 \% \mathrm{CI}: 60$ to $410 \mathrm{~kg} / \mathrm{ha}$ ) and imidacloprid plus fluopyram ( $250 \mathrm{~kg} / \mathrm{ha}, P=0.0330 ; 95 \%$ CI: 20 to $480 \mathrm{~kg} / \mathrm{ha}$ ) within the moderate group. Conversely, when imidacloprid was followed by acephate, yield was not significantly different compared with phorate (70 $\mathrm{kg} / \mathrm{ha}, P=0.7104 ; 95 \% \mathrm{CI}:-320$ to $460 \mathrm{~kg} / \mathrm{ha})$. In-furrow treatment with phorate corresponded to significantly greater yield than imidacloprid plus fluopyram for the moderate but not susceptible group $(-200 \mathrm{~kg} / \mathrm{ha}, P=0.1255)$, whereas the reverse was the case for imidacloprid alone compared with imidacloprid plus fluopyram: 20 $\mathrm{kg} / \mathrm{ha}(P=0.8985 ; 95 \%$ CI: -220 to $250 \mathrm{~kg} / \mathrm{ha})$ and $-350 \mathrm{~kg} / \mathrm{ha}(P$ $=0.0093 ; 95 \%$ CI: 90 to $620 \mathrm{~kg} / \mathrm{ha}$ ), respectively.

Projected yield increase and return. For susceptible cultivars, a larger variation in treatment responses was observed. Treatment with imidacloprid, imidacloprid plus fluopyram, phorate, and imidacloprid followed by acephate had 50.3, 90.7, 72.2, and $97.7 \%$ chance, respectively, of increasing yield by at least $100 \mathrm{~kg} / \mathrm{ha}$ and $50 \%$ chance of increasing yield by $100,450,250$, and $620 \mathrm{~kg} / \mathrm{ha}$, respectively (Fig. 3A). For moderately susceptible cultivars, treatment with imidacloprid, imidacloprid plus fluopyram, phorate, and imidacloprid followed by acephate had 73.5, 70.7, 93.8, and $96.4 \%$ chance, respectively, of increasing yield by at least $100 \mathrm{~kg} / \mathrm{ha}$ and $50 \%$ chance of increasing yield by $260,240,490$, and $570 \mathrm{~kg} / \mathrm{ha}$, respectively (Fig. 3B). From the resistant group data, the available yield projections were quite similar. Imidacloprid had a $75.5 \%$ probability of increasing yield by at least $100 \mathrm{~kg} / \mathrm{ha}$, and it was $50 \%$ likely to increase yield by $280 \mathrm{~kg} / \mathrm{ha}$, whereas phorate had an $80.3 \%$ chance to increase yield by $100 \mathrm{~kg} / \mathrm{ha}$ and a $50 \%$ probability of increasing yield by $320 \mathrm{~kg} / \mathrm{ha}$ (Fig. 3E).

For susceptible cultivars, treatment with imidacloprid, imidacloprid plus fluopyram, phorate, and imidacloprid followed by acephate had $50 \%$ probability of increasing returns by at least $\$ 25,127,76$, and 250/ha, respectively (Fig. 3B). For moderately susceptible cultivars, treatment with imidacloprid, imidacloprid plus fluopyram, phorate, and imidacloprid followed by acephate had $50 \%$ chance of increasing returns over the untreated check by at least $\$ 102,30$, 194, and 225/ha, respectively (Fig. 3D). As is evident from the overlapping curves in Figure 3F, resistant cultivars treated with imidacloprid or phorate were equivalently profitable, and both had a $50 \%$ chance of a $\$ 110 /$ ha return.

\section{Discussion}

TSW occurs in all U.S. peanut-producing states, and it is a devastating disease that can stunt peanuts, reduce yields, and limit grower profitability (Culbreath et al. 2009; Kokalis-Burelle et al. 1997; Sherwood et al. 2009). In 2017 alone, peanut losses because of TSW in the southeastern United States were estimated at approximately 3\% (Kemerait et al. 2018) or \$38 million (USDA NASS 2019). Available management options outside cultivar resistance for TSW are primarily oriented toward managing its vector, thrips, and in-furrow insecticides are an important component in an effective IPM approach in mitigating TSW (Brandenburg et al. 2019; Srinivasan et al. 2017).

This study examined the effects of commonly used in-furrow pesticide treatments, one followed by a broadcast application of acephate 21 days later, on the efficacy of TSW management relative to an untreated control in South Carolina for cultivar groups varying in susceptibility to TSW. The results of the meta-analysis demonstrated insecticide treatment differences in TSW incidence, potential yield increases, and returns, with these differences additionally
A

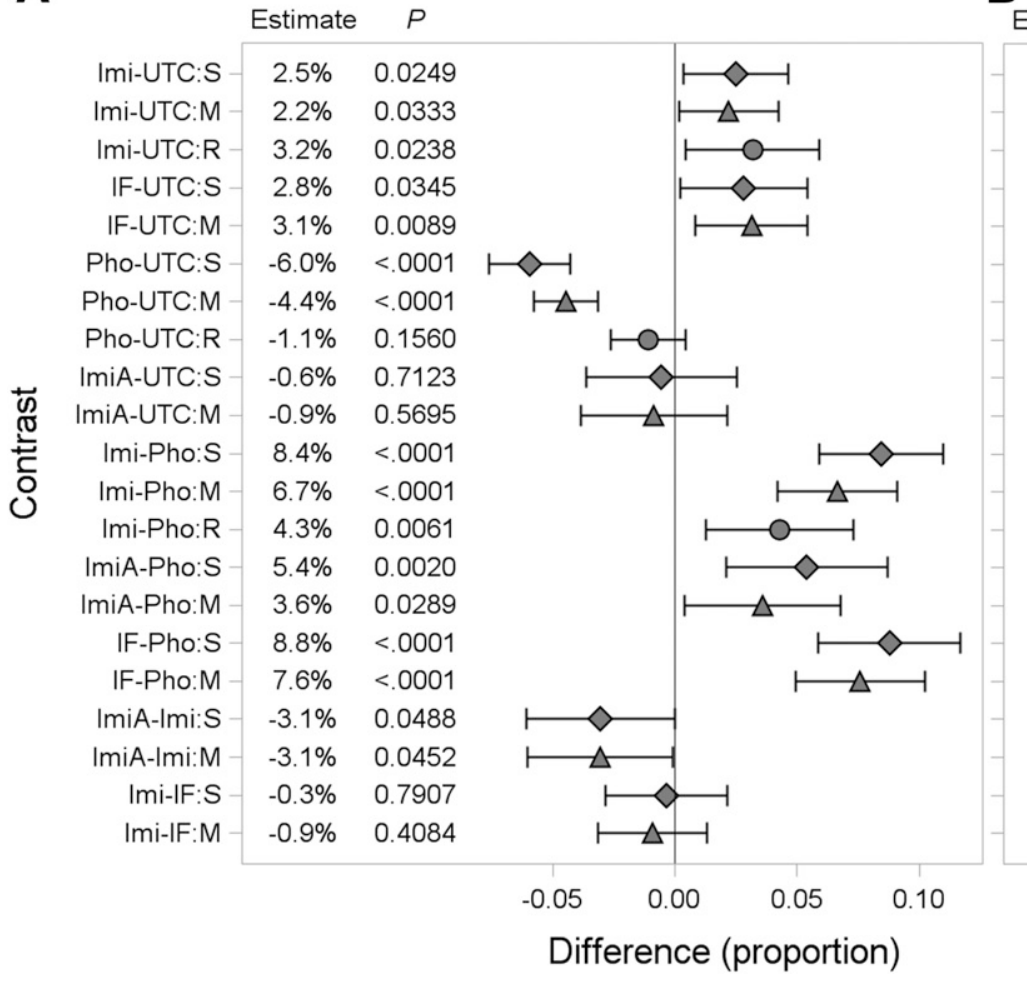

B Estimate $P$

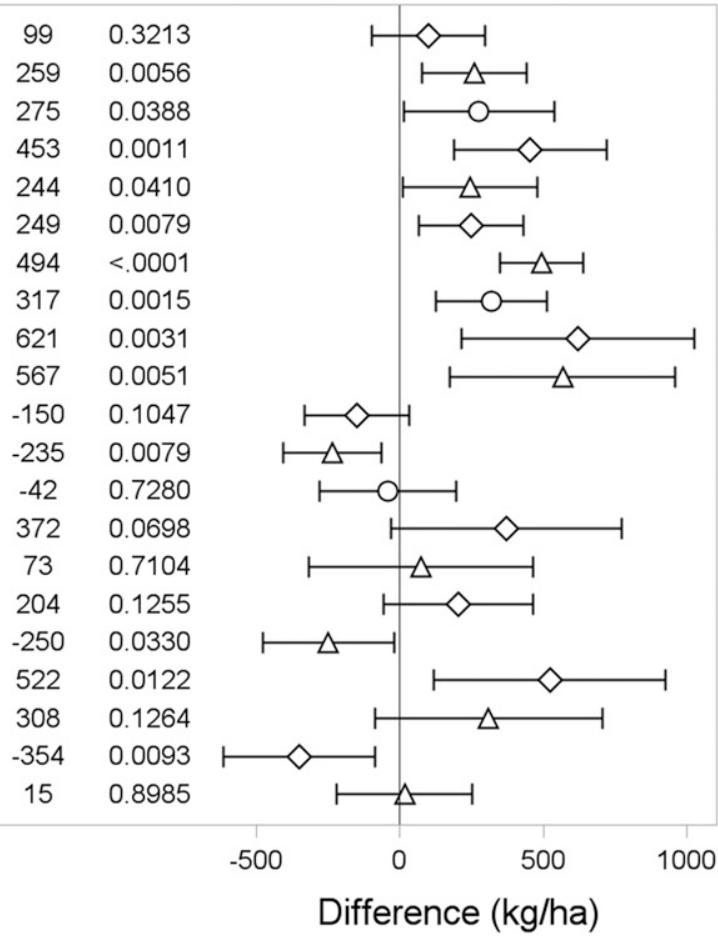

Fig. 2. Meta-analytic-derived contrasts of least squares means of insecticide treatments among cultivar susceptibility groups for $\mathbf{A}$, spotted wilt management and B, associated yield. Peanut cultivar spotted wilt susceptibility groups are susceptible (S; diamonds), moderate (M; triangles), and resistant (R; circles). Error bars are estimated $95 \%$ confidence intervals. Listed contrast difference estimates in B are in kilograms per hectare. IF, imidacloprid plus fluopyram; Imi, imidacloprid; ImiA, imidacloprid followed by acephate 21 days after planting; Pho, phorate; UTC, untreated control. 
influenced by cultivar susceptibility, and the largest treatment differences were associated with the susceptible group. Similar to previous reports, imidacloprid increased, whereas phorate decreased TSW incidence (Culbreath and Srinivasan 2011; Culbreath et al. 2008; Marasigan et al. 2016, 2018; Srinivasan et al. 2017), although this response from phorate was attenuated with resistant cultivars (e.g., Bailey, Sullivan, and TUFRunner 297). Subsequent acephate application reduced TSW incidence and increased yield for imidacloprid treatment, although significance depended on cultivar susceptibility.
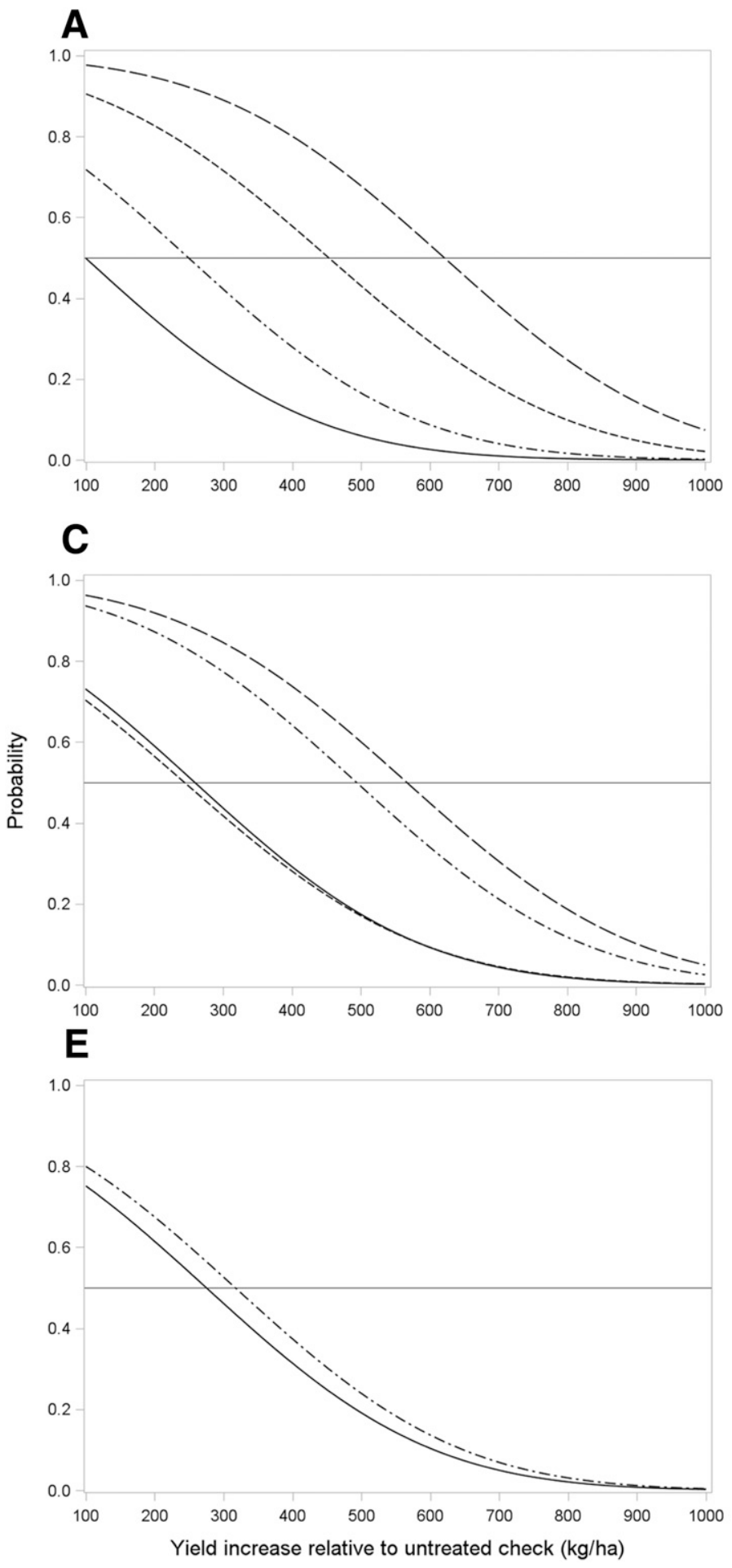

Framing results in the context of the probability of yield increase and return allows growers, Extension personnel, consultants, and related stakeholders to consider the likelihood of treatments having a specific outcome. Although this work examined effects of insecticide treatments, several previous studies have likewise utilized this methodology to examine the cost-benefit of fungicide programs (Paul et al. 2008; Sylvester et al. 2018; Willyerd et al. 2015). Although imidacloprid plus fluopyram contributed a greater yield increase over the untreated control than imidacloprid alone did with susceptible cultivars, these two pesticides exhibited similar yield

B

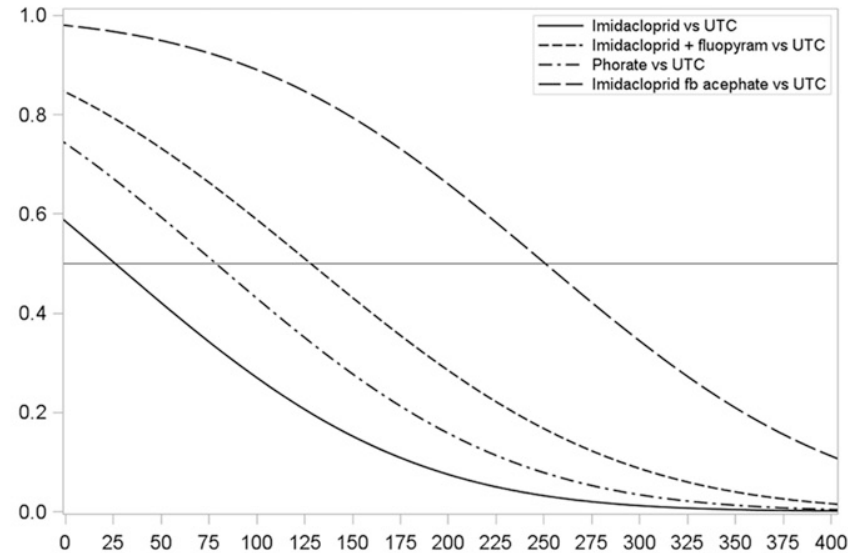

D

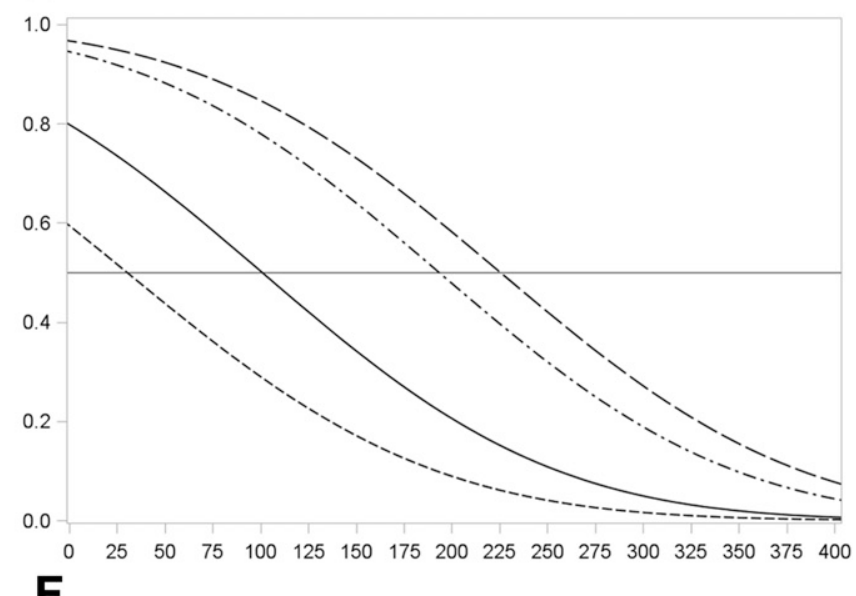

$\mathbf{F}$

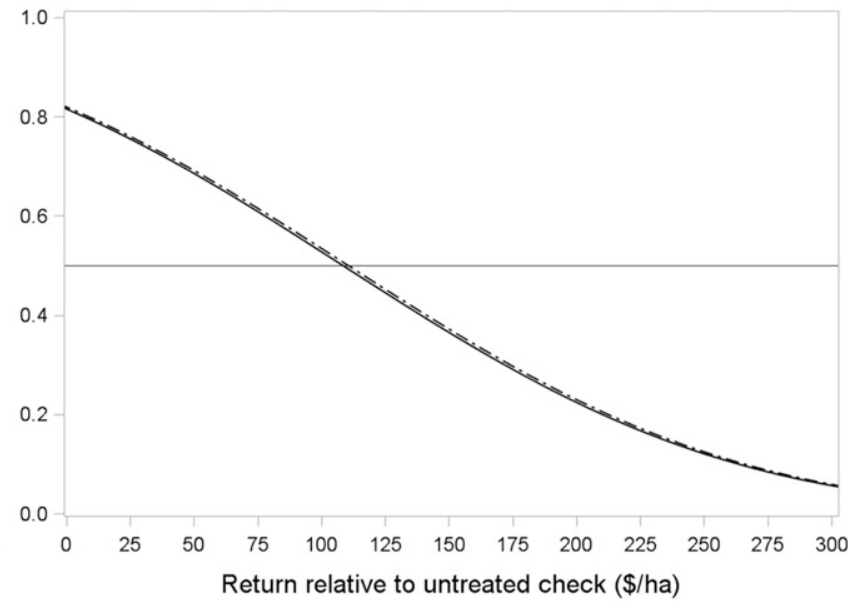

Fig. 3. Estimated probability of insecticide treatments resulting in A, C, and E, yield increase and B, D, and F, return relative to the untreated control (UTC) for peanut cultivars $A$ and $B$, susceptible, $C$ and $D$, moderately susceptible, and $E$ and F, resistant to tomato spotted wilt virus. Insecticide treatments relative to a UTC included imidacloprid, imidacloprid plus fluopyram, phorate, and imidacloprid followed by acephate 21 days after planting. 
responses over the untreated control when paired with moderately susceptible cultivars. When product application costs and harvest values $(\$ 468.5 / 1,000 \mathrm{~kg})$ were factored in, imidacloprid plus fluopyram contributed a greater return with the susceptible group but a lower return than imidacloprid alone for the moderate group. Yields and returns following phorate were greater compared with imidacloprid for susceptible and moderate cultivar groups, but unsurprisingly, there was not a marked difference between these treatments when used with resistant cultivars. Imidacloprid increased TSW incidence on resistant cultivars, whereas phorate did not significantly reduce TSW incidence as with other susceptibilities. In these cultivars, the phenotype of genetic resistance by itself seems to have been great enough to effectively mask additional induction of host resistance from phorate (Culbreath et al. 2008; Jain et al. 2015), whereas phytotoxic responses of this organophosphate compound characteristically occurred on resistant as well as more susceptible cultivars (Culbreath et al. 2003; Herbert et al. 2007; Marasigan et al. 2016). The consistent increase in TSW incidence following treatment with imidacloprid across the three cultivar groups, however, is consistent with the understanding that this neonicotinoid affects thrips feeding behavior and leads to increased inoculations of peanut plants (Chaisuekel and Riley 2001; Culbreath et al. 2003; Culbreath and Srinivasan 2011; Riley 2007).

On an individual treatment basis, phorate was more likely to provide the greatest return for moderately susceptible cultivars, whereas imidacloprid plus fluopyram was more likely to generate the greatest returns for susceptible cultivars. When a postemergent application of acephate was considered, the profitability of phorate treatment alone was readily exceeded for the susceptible group, but it was only slightly less profitable for the moderate group. Imidacloprid followed by acephate increased yield and return compared with the untreated control greater than imidacloprid alone. Resistant cultivars treated with both in-furrow insecticide and postemergent acephate were not represented in this work.

In our study, peanut contract price was set at $\$ 468.5 / 1,000 \mathrm{~kg}$. Contract price itself can vary across years, regions, and market types. Depending on the buying point and market circumstances, additional conditions may further add a premium to a base contract price, including cultivar high-oleic status and production for seed. However, factors such as excessive kernel damage leading to segregation II grade classification or detection of Aspergillus flavus can penalize the value of a given load of farmer stock peanuts (USDA FSA 2018). To generalize the profitability estimates of this study to alternate contract prices, new returns at a specified probability, $p$, can be estimated as:

$$
\begin{aligned}
\text { new return at } p= & (\text { new contract price }) /(\text { current contract price; } \\
& \text { e.g., } \$ 468.5) \times \text { current return at } p .
\end{aligned}
$$

While the results from these analyses are useful in weighing the cost-benefit of an individual insecticide option for thrips and subsequent TSW management, it is also valuable to understand the context of these results. Outside of varying thrips (data not presented because it was not available for many studies) and TSW pressure, the studies included herein were relatively free of additional pests that might influence the choice of one in-furrow product over another. Included among these are early-season leaf spot and nematode pressure. The fluopyram component of imidacloprid plus fluopyram has both fungicidal and nematicidal activities (Faske and Hurd 2015; Jackson et al. 2014; Oka and Saroya 2019; Proffer et al. 2013; Veloukas and Karaoglanidis 2012), and as such, the absence of notable infections or damage from pathogenic fungi or nematodes from the examined data does not necessarily reflect the performance of this combination under production conditions where nematodes or early-season leaf spot pressure may be present or not adequately managed in contrast to those included within the present meta-analyses. Accordingly, the value of imidacloprid plus fluopyram would be anticipated to be greater under such conditions, although published reports on the efficacy of imidacloprid plus fluopyram in furrow on peanut are currently limited despite this combination having been labeled for use on peanut since 2015 (Faske and Hurd 2015); however, there are several informative Plant Disease Management Reports with this treatment on peanut. Interestingly, 60 years after its initial registration on peanut (US EPA 2001), data documenting suppression of late leaf spot (LLS; causal agent Nothopassalora personata [Berk \& MA Curtis] SA Khan \& M Kamal) following phorate application in furrow have been collected (D. Anco, unpublished data). As such, although the results of the current study may underestimate the value of imidacloprid plus fluopyram under conditions including early-season leaf spot pressure, it likewise seems to undervalue phorate use in those same conditions. Pressure from LLS overall has been increasing in South Carolina in both prevalence and time of development, in part because of adverse weather during harvest in 2015, 2016, and 2018; corresponding volunteer emergence in subsequent growing seasons; peanut acreage in the state having increased $12.2 \times$ from 4,047 ha in 2002 to 49,372 ha in 2017 (USDA NASS 2019); and loss of field resistance in the widely grown Virginia-type cultivar Bailey (Anco et al. 2018). Although LLS infections on planted peanut typically are not observed until much later in the growing season, sporulating lesions of LLS have been found on volunteer peanuts in South Carolina as early as the fourth week of May when peanut planting is not yet complete. In addition to the integration of resistance and cultural practices to reduce leaf spot risk, use of in-furrow products contributing leaf spot protection is increasingly being considered among growers in the state.

Another factor that was outside the scope and not formally quantitatively addressed in this analysis is convenience. An increasing number of producers in and outside South Carolina have opted for liquid formulations (e.g., imidacloprid and imidacloprid plus fluopyram) (Brandenburg et al. 2019; Morgan et al. 2014; Srinivasan et al. 2017) based in part on their ease and consistency of application compared with granular products (e.g., phorate). Nevertheless, phorate continues to be a commonly utilized in-furrow insecticide and remains the only available in-furrow product that reduces TSW levels beyond thrips control alone (McKinney and Tillman 2017; Tillman et al. 2006; Wiatrak et al. 2000); the results of this study similarly corroborate the value of this granular option. In the same vein, while there is no effort here to argue against use of a product on the grounds of it simply being more convenient (something the authors readily appreciate), having this work performed over the collective dataset provides a convenient (no pun intended) resource to reference approximate opportunity tradeoffs of utilizing one product over another. For example, the projected return results demonstrate that, on average, use of the less convenient granular phorate with moderately susceptible cultivars is equally probable at the $50 \%$ level of generating \$90/ha greater returns than liquid imidacloprid and \$160/ha greater returns than liquid imidacloprid plus fluopyram. Personal preferences each have a relative value associated with them. Still, in years when production budgets provide a narrow window for profit or when interest in optimizing anticipated net harvest value outweighs one's aversion to the relative inconvenience of a specific application, having the projected returns for several products in a single place can serve as a reference to consider during the decision-making process. Although moderate cultivars treated with imidacloprid followed by acephate had a greater projected return versus the nontreated control at an individual level than phorate, assuming a subsidized cost of physically applying the postemergent insecticide, the overall difference between these treatments was not significant. In addition, the greater precision of the difference between phorate and the nontreated control corresponded to the width of its 95\% CI being approximately $35 \%$ that of the two-application treatment. For susceptible cultivars, the $95 \%$ CIs for imidacloprid, imidacloprid plus phorate, and phorate overlapped considerably when converted to projected return at the $50 \%$ probability level: $\$-70$ to 120,0 to 250 , and -10 to $160 /$ ha, respectively. For this susceptibility group, returns following individual product choice were more comparable, and as such, they can be interpreted to afford more flexibility in product selection. For susceptible cultivars, although imidacloprid followed by acephate versus the untreated control still exhibited a larger 95\% CI width than other treatments in 
the same susceptibility group, the amount of overlap with the upper range of the next highest return-generating treatment, imidacloprid plus fluopyram at the $50 \%$ probability level, was only approximately $35 \%$ compared with overlapping $100 \%$ in the analogous top two return-generating treatments in the moderate group.

Similarly, although it was the intention here for contrasts to examine treatment differences within susceptibility groups, it can also be seen that, relative to nontreated controls, the potential for relative profitability as a function of the use of an in-furrow pesticide and potentially, a postemergence application of systemic insecticide was greater for susceptible and moderately susceptible cultivars than it was for resistant cultivars. Pending the practical logistics involved with acquiring seed and securing production contracts for specific resistant cultivars, use of a cultivar with greater resistance than one more susceptible by itself would be a choice that affords a considerable amount of convenience. Nevertheless, production decisions by their practical purpose take into consideration multiple factors that can or may be perceived to relate to end profitability or personal preferences. Along these lines, this work aimed to produce results capable of being applied to cultivars that are grouped into interpretable classes and, in doing so, preserves a certain generality for which cross-cultivar contrasts would arguably oppose based on genotypespecific yield responses, unless of course future cultivars of interest exhibit identical relative yield potentials under the same production considerations as those examined in this work. This, however, is variable, and as such, it was not conducted.

\section{Acknowledgments}

Appreciation is given to AMVAC Chemical and Bayer CropScience for providing product for testing and Georgia Seed Development for providing seed. Thanks go to four anonymous reviewers whose helpful comments ultimately improved this manuscript. This work is technical contribution no. 6768 of the Clemson University Experiment Station.

\section{Literature Cited}

Anco, D., Thomas, J. S., Marshall, M., Smith, N., Kirk, K. R. 2018. Peanut moneymaker 2018 production guide. Clemson University Extension Circular 588. Clemson University Extension, Clemson, SC.

Brandenburg, R. L. 2017. Peanut insect and mite management. Pages 81-99 in: 2017 Peanut information. North Carolina Cooperative Extension Service Publication AG-331, North Carolina Cooperative Extension Service, Raleigh, NC.

Brandenburg, R. L., Jordan, D. L., Royals, B. R., Mahoney, D. J., and Johnson, P. D. 2019. Utilization of imidacloprid to control thrips in peanut in North Carolina. Peanut Sci. 46:8-13.

Cantonwine, E. G., Culbreath, A. K., Stevenson, K. L., Kemerait Jr., R. C., Brenneman, T. B., Smith, N. B., and Mullinix Jr., B. G. 2006. Integrated disease management of leaf spot and spotted wilt of peanut. Plant Dis. 90: 493-500.

Chaisuekel, C., and Riley, D. G. 2001. Thrips (Thysanoptera: Thripidae) feeding response to concentration of imidacloprid in tomato leaf tissue. J. Entomol. Sci. 36:315-317.

Childers, C. C., Duncan, L. W., Wheaton, T. A., and Timmer, L. W. 1987. Arthropod and nematode control with aldicarb on Florida citrus. J. Econ. Entomol. 80:1064-1071.

Costa, A. 1941. Uma moléstia de vírus do amendoim (Arachis hypogaea L.), a mancha anular. Biologico 7:249-251.

Culbreath, A., and Srinivasan, R. 2011. Epidemiology of spotted wilt disease of peanut caused by Tomato spotted wilt virus in the southeastern U.S. Virus Res. 159:101-109.

Culbreath, A., Tillman, B., Gorbet, D., Holbrook, C., and Nischwitz, C. 2008. Response of new field-resistant peanut cultivars to twin-row pattern or infurrow applications of phorate for management of spotted wilt. Plant Dis. 92: 1307-1312.

Culbreath, A., Todd, J., Demski, J., and Chamberland, J. 1992. Disease progress of spotted wilt in peanut cultivars Florunner and Southern Runner. Phytopathology 82:766-771.

Culbreath, A. K., Selph, A. C., Williams, B. W., Kemerait, Jr., R. C., Srinivasan, R., Abney, M. R., Tillman, B. L., Holbrook, C. C., and Branch, W. D. 2016. Effects of new field resistant cultivars and in-furrow applications of phorate insecticide on tomato spotted wilt of peanut. Crop Prot. 81:70-75.

Culbreath, A. K., Todd, J. W., and Brown, S. L. 2003. Epidemiology and management of tomato spotted wilt in peanut. Annu. Rev. Phytopathol. 41: 53-75.

Culbreath, A. K., Todd, J. W., Gorbet, D. W., Shokes, F. M., and Pappu, H. R. 1997. Field response of new peanut cultivar UF 91108 to tomato spotted wilt virus. Plant Dis. 81:1410-1415.
Faske, T. R., and Hurd, K. 2015. Sensitivity of Meloidogyne incognita and Rotylenchulus reniformis to fluopyram. J. Nematol. 47:316-321.

Halliwell, R., and Philley, G. 1974. Spotted wilt of peanut in Texas. Plant Dis. Rep. 58:23-25.

Hedges, L. V., Gurevitch, J., and Curtis, P. S. 1999. The meta-analysis of response ratios in experimental ecology. Ecology 80:1150-1156.

Herbert, D. A., Malone, S., Aref, S., Brandenburg, R. L., Jordan, D. L., Royals, B. M., and Johnson, P. D. 2007. Role of insecticides in reducing thrips injury to plants and incidence of Tomato spotted wilt virus in Virginia market type peanut. J. Econ. Entomol. 100:1241-1247.

Hurt, C., Brandenburg, R., Jordan, D., Kennedy, G., and Bailey, J. 2005. Management of spotted wilt vectored by Frankliniella fusca (Thysanoptera: Thripidae) in Virginia market-type peanut. J. Econ. Entomol. 98:1435-1440.

Jackson, C. S., Faske, T. R., and Kirkpatrick, T. L. 2014. Assessment of fluopyram for suppression of root-knot nematode (Meloidogyne incognita) in soybean. Pages 65-67 in: Arkansas Soybean Research Studies 2014. J. Ross, ed. University of Arkansas, Fayettville, AK.

Jain, M., Gallo, M., Chengalrayan, K., Shaikh, N., MacDonald, G., and Davis, J. 2015. Phorate-induced host defence responses condition acquired resistance to Tomato spotted wilt in cultivated peanut (Arachis hypogaea L.). J. Phytopathol. 163:853-866.

Jordan, D. L., Hare, A. T., Roberson, G. T., Shew, B. B., Brandenburg, R. L., Anco, D., Balota, M., Mehl, H., and Taylor, S. 2018a. Summary of variables associated with application of plant protection products in peanut. Crop Forage Turfgrass Manage. 4:180034.

Jordan, D. L., Johnson, P. D., Hare, A. T., Anco, D., Chapin, J., Thomas, J., Monfort, S., and Balota, M. 2018b. Influence of inoculation with Bradyrhizobia and nitrogen rate on yield and estimated economic return of Virginia market-type peanut. Crop Forage Turfgrass Manage. 4:180002.

Kemerait, R., Culbreath, A., Prostko, E., Brenneman, T., Tubbs, S., Srinivasan, R., Abney, M., Monfort, S., Rabinowitz, A., Tillman, B., Dufault, N., Rowland, D., Mulvaney, M., Small, I., Hagan, A., Sarver, J., Anco, D., and Smith, N. 2018. Peanut Rx-Minimizing Diseases of Peanut in the Southeastern United States. The 2018 Version of the Peanut Disease Risk Index. University of Georgia Extension. https://peanuts.caes.uga.edu/content/dam/caes-subsite/peanuts/docs/ 2018/2018-Peanut-Rx-Disease-Risk-Index.pdf

Kokalis-Burelle, N., Porter, D. M., Rodríguez-Kábana, R., Smith, D. H., and Subrahmanyam, P. 1997. Compendium of Peanut Diseases, 2nd Ed. APS Press, St. Paul, MN.

Littell, R. C., Milliken, G. A., Stroup, W. W., Wolfinger, R. D., and Schabenberger, O. 2006. SAS System for Mixed Models, 2nd Ed. SAS Institute Inc., Cary, NC.

Madden, L. V., and Paul, P. A. 2011. Meta-analysis for evidence synthesis in plant pathology: An overview. Phytopathology 101:16-30.

Madden, L. V., Piepho, H. P., and Paul, P. A. 2016. Statistical models and methods for network meta-analysis. Phytopathology 106:792-806.

Mahoney, D. J., Jordan, D. L., Brandenburg, R. L., Royals, B. R., Inman, M. D., Hare, A. T., and Shew, B. B. 2018. Influence of planting date and insecticide on injury caused by tobacco thrips and peanut yield in North Carolina. Peanut Sci. 45:70-74.

Marasigan, K., Toews, M., Kemerait, R., Abney, M., Culbreath, A., and Srinivasan, R. 2016. Evaluation of alternatives to carbamate and organophosphate insecticides against thrips and Tomato spotted wilt virus in peanut production. J. Econ. Entomol. 109:544-557.

Marasigan, K., Toews, M., Kemerait Jr., R., Abney, M., Culbreath, A., and Srinivasan, R. 2018. Evaluation of alternatives to an organophosphate insecticide with selected cultural practices: Effects on thrips, Frankliniella fusca, and incidence of spotted wilt in peanut farmscapes. J. Econ. Entomol. 111:1030-1041.

McKinney, J., and Tillman, B. 2017. Spotted wilt in peanut as impacted by genotype resistance, planting date, and plant population. Crop Sci. 57:130-136

Mehl, H. L. 2017. Evaluation of new high oleic Virginia-type peanut cultivars for disease tolerance, yield, and quality. Peanut Sci. 44:100-110.

Minton, N. A., and Morgan, L. W. 1974. Evaluation of systemic and nonsystemic pesticides for insect and nematode control in peanuts. Peanut Sci. 1:91-98.

Morgan, J., Carroll, M., Smith, P., Rhodes, R., Cochran, A., Bradley, A., Drake, W., Ellison, C., Whitehead, A., Tyson, C., Smith, M., Britton, T., Harrell, N., Fountain, C., Thagard, R., Malloy, M., Grimes, L., Shaw, M., Harrelson, R., Jordan, D. L., Johnson, P. D., Brandenburg, R. L., Shew, B. B., Wells, K., Parrish, M., Slade, G., Spencer, J., Reiter, J., Council, B., Marcus, W., Balota, M., Herbert, A., and Mehl, H. 2014. Survey of key production and pest management practices in peanut in North Carolina and Virginia during 2013. Proc. Am. Peanut Res. Educ. Soc. 46:22-23.

Ngugi, H. K., Lehman, B. L., and Madden, L. V. 2011. Multiple treatment metaanalysis of products evaluated for control of fire blight in the eastern United States. Phytopathology 101:512-522.

Oka, Y., and Saroya, Y. 2019. Effect of fluensulfone and fluopyram on the mobility and infection of second-stage juveniles of Meloidogyne incognita and M. javanica. Pest Manag. Sci. 75:2095-2106.

Pappu, H., Jones, R., and Jain, R. 2009. Global status of tospovirus epidemics in diverse cropping systems: Successes achieved and challenges ahead. Virus Res. 141:219-236.

Parrella, G., Gognalons, P., Gebre-Selassiè, K., Vovlas, C., and Marchoux, G. 2003. An update of the host range of Tomato spotted wilt virus. J. Plant Pathol. 85:227-264. 
Paul, P. A., Lipps, P. E., Hershman, D. E., McMullen, M. P., Draper, M. A., and Madden, L. V. 2007. A quantitative review of tebuconazole effect on Fusarium head blight and deoxynivalenol content in wheat. Phytopathology 97:211-220.

Paul, P. A., Lipps, P. E., Hershman, D. E., McMullen, M. P., Draper, M. A., and Madden, L. V. 2008. Efficacy of triazole-based fungicides for Fusarium head blight and deoxynivalenol control in wheat: A multivariate meta-analysis. Phytopathology 98:999-1011.

Piepho, H. P., Williams, E. R., and Madden, L. V. 2012. The use of two-way linear mixed models in multitreatment meta-analysis. Biometrics 68:1269-1277.

Proffer, T. J., Lizotte, E., Rothwell, N. L., and Sundin, G. W. 2013. Evaluation of dodine, fluopyram and penthiopyrad for the management of leaf spot and powdery mildew of tart cherry, and fungicide sensitivity screening of Michigan populations of Blumeriella jaapii. Pest Manag. Sci. 69:747-754.

Riley, D. G. 2007. Effect of imidacloprid on settling behavior of Franliniella occidentalis and Frankliniella fusca (Thysanoptera: Thripidae) on tomato and peanut. J. Entomol. Sci. 42:74-83.

Sherwood, J. L., German, T. L., Moyer, J. W., and Ullman, D. E. 2009. Tomato spotted wilt. Plant Health Instructor doi:10.1094/PHI-I-2003-0613-02.

Smith, J. C. 1972. Tobacco thrips-nematode control on Virginia-type peanuts. J. Econ. Entomol. 65:1700-1703.

Srinivasan, R., Abney, M., Culbreath, A., Kemerait, R., Tubbs, R., Monfort, W., and Pappu, H. R. 2017. Three decades of managing Tomato spotted wilt virus in peanut in southeastern United States. Virus Res. 241:203-212.

Sylvester, N. P., Dalla Lana, F., Mehl, H., Collins, A., Paul, P. A., and Kleczewski, N. M. 2018. Evaluating the profitability of foliar fungicide programs in midAtlantic soft-red winter wheat production. Plant Dis. 102:1627-1637.
Tillman, B., Gorbet, D., Culbreath, A., and Todd, J. 2006. Response of peanut cultivars to seeding density and row patterns. Plant Health Progr. 5. doi: https://doi.org/10.1094/CM-2006-0711-01-RS.

Todd, J., Culbreath, A., Chamberlin, J., Beshear, R., and Mullinix, B. 1995 Colonization and population dynamics of thrips in peanuts in the southern United States. NATO Adv. Sci. Inst. Se. 276:453-460.

US EPA. 2001. Interim Reregistration Eligibility Decision for Phorate. US EPA Washington DC. https://archive.epa.gov/pesticides/reregistration/web/ pdf/phorate_ired.pdf

USDA FSA. 2018. Peanut Premiums and Discounts for 2018 Crop Year. USDA FSA. https://www.fsa.usda.gov/Assets/USDA-FSA-Public/usdafiles/Price-Support/ pdf/2018/2018_peanuts.pdf

USDA NASS. 2019. USDA NASS. https://www.nass.usda.gov/

van Houwelingen, H. C., Arends, L. R., and Stijnen, T. 2002. Advanced methods in meta-analysis: Multivariate approach and meta-regression. Stat. Med. 21: 589-624.

Veloukas, T., and Karaoglanidis, G. S. 2012. Biological activity of the succinate dehydrogenase inhibitor fluopyram against Botrytis cinerea and fungal baseline sensitivity. Pest Manag. Sci. 68:858-864.

Whitehead, A. 2002. Meta-Analysis of Controlled Clinical Trials. John Wiley \& Sons, West Sussex, England.

Wiatrak, P. J., Wright, D. L., and Marois, J. J. 2000. Conservation tillage and Thimet effects on Tomato spotted wilt virus in three peanut cultivars. Proc. Soil Crop Sci. Soc. Fla. 59:109-111.

Willyerd, K. T., Bradley, C. A., Chapara, V., Conley, S. P., Esker, P. D., Madden, L. V., Wise, K. A., and Paul, P. A. 2015. Revisiting fungicide-based management guidelines for leaf blotch diseases in soft red winter wheat. Plant Dis. 99:1434-1444 